\title{
THE USE OF HEU-TYPE ZEOLITIC TUFF IN SUSTAINABLE AGRICULTURE: EXPERIMENTAL STUDY ON THE DECREASE OF NITRATE LOAD IN VADOSE ZONE LEACHATES
}

\section{Hatzigiannakis E. ${ }^{1}$, Kantiranis N. ${ }^{2}$, Tziritis E. ${ }^{1}$, Filippidis A. ${ }^{2}$, Arampatzis G. ${ }^{1}$ and Tzamos E. ${ }^{2}$}

${ }^{1}$ Hellenic Agricultural Organization, Soil and Water Resources Institute 57400, SindosThessaloniki, Greece,hatzigiannakis@gmail.com,tziritis@gmail.com,arampgeo@gmail.com

${ }^{2}$ Aristotle University of Thessaloniki, Faculty of Sciences, School of Geology, Department of Mineralogy-Petrology-Economic Geology, 54124, Thessaloniki, Greece, kantira@geo.auth.gr, anestis@geo.auth.gr,tzamos@geo.auth.gr

\begin{abstract}
A HEU-type zeolitic tuff of very-high quality ( $88 \mathrm{wt} . \%$ clinoptilolite-heulandite) has been used as an additive to natural soils, aiming to reduce the produced nitrate load in leachates, following a common irrigation scheme. Zeolitic tuff has been added and mixed with agricultural soil in three different proportions (0.2, 0.4 and $0.6 \%)$ corresponding to an application of 500, 1000 and $1500 \mathrm{~kg}$ per acre. The control soil (without zeolitic tuff) and the three mixtures were exposed in a ten weeks experiment, in which, specific doses of irrigation water enriched in nitrates were added. Results of leachates analyses revealed that the addition of $0.2 \%$ zeolitic tuff is not effective and the mixture of soil-zeolitic tuff appears to have similar behaviour with the untreated (reference) soil sample. On the contrary, zeolitic tuff additions by $0.4 \%$ and $0.6 \%$ showed remarkable results and reduced the nitrate load of leachates by 81 and $86 \%$, respectively. Hence, the impacts from the application of very-high quality HEUtype zeolitic tuff in agricultural soils could be rather positive towards environmental protection and rational farming, an in line with the goals and objectives of the new common agricultural policy imposed by European Union.
\end{abstract}

Keywords: zeolite, agriculture, nitrates, environmental protection, leachates.

\section{Пєрí $\eta \psi \eta$}

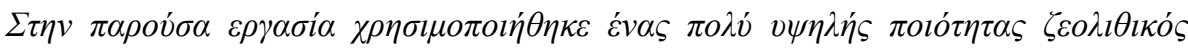

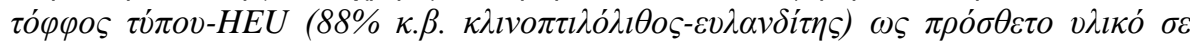

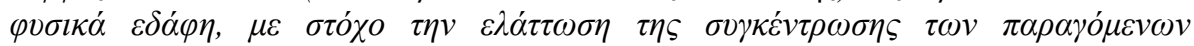

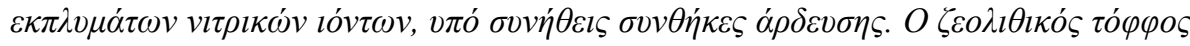

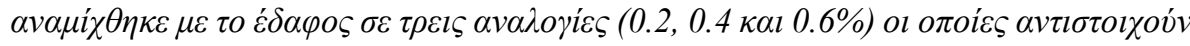

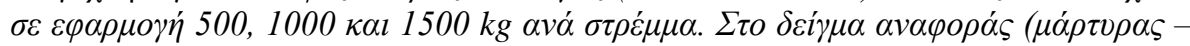

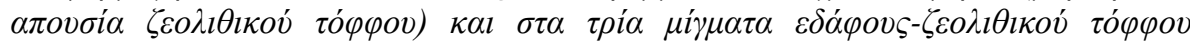

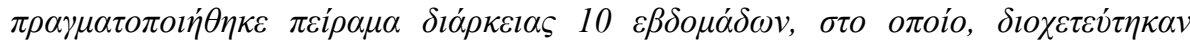

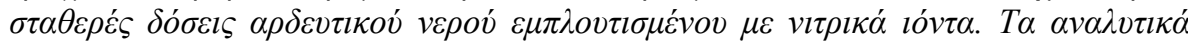

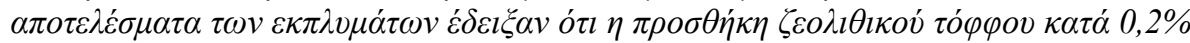

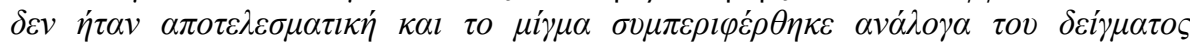




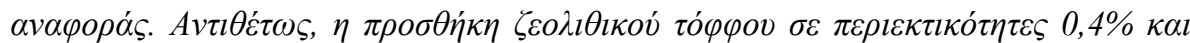

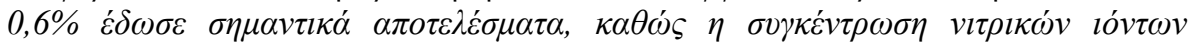

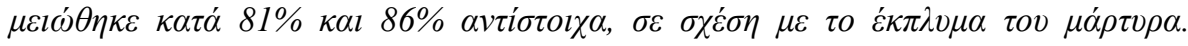

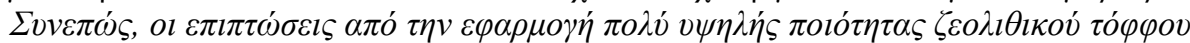

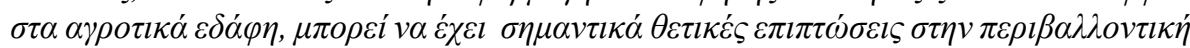

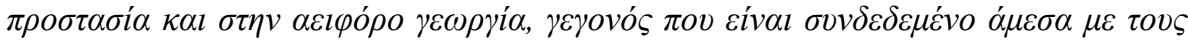

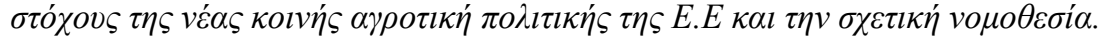

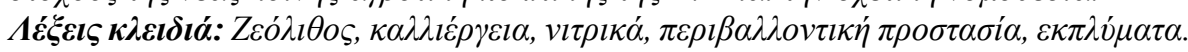

\section{Introduction}

Soil and water quality deterioration has become a significant challenge due to population growth combined with other man-made activities, like e.g. irrational agriculture and industrialization. As a result, a considerable increment of contaminants has been recorded worldwide in the aforementioned compartments, denoting a significant impact to their overall quality and environmental characteristics.

Agricultural areas are by definition vulnerable to environmental pressures related with excessive use of fertilizers and agrochemicals. Nitrogen leaching from cropland contributes to increased nitrate levels in ground and surface water (Lichtenberg and Shapiro, 1997) and constitutes a focal point for European legislation (Council Directive, 1991) in terms of environmental protection and mitigation of potential threats. Depending on the concentration, elevated $\mathrm{N}$ levels may cause adverse effects to aquatic ecosystems and humans, particularly to infants and also result in collateral financial impacts for farmers due to the expense of fertilizers (Perrin et al., 1998).

Nitrates $\left(\mathrm{NO}_{3}\right)$ are present to some degree in almost all cropland, except flooded soils. Depending on soil's leaching potential, when water is added in excess of the soil's field capacity (e.g. through precipitation and/or irrigation) it will carry nitrate and other salts downward. Controlling nitrate leaching can be a challenge for farmers because it requires simultaneous management of two essentials of plant growth; nitrogen $(\mathrm{N})$ and water. Any factor influencing soil moisture (such as rainfall, irrigation, evaporation and transpiration) will impact nitrate movement. In general, more water infiltration results in nitrate moving deeper in the profile. Soil properties also have a major impact on the extent of nitrate movement. However, the extent of nitrate movement to groundwater depends on the underlying soil and bedrock conditions, as well as depth to groundwater.

Nitrate in a field may originate from many sources, including manures, composts, decaying plants, septic tanks, or from fertilizer which is rather common in agricultural soils. Nitrate behaviour does not depend on its sources; the simple fact is that any nitrate available for plant uptake is vulnerable to leaching loss. One key practice for reducing leaching losses is to minimize the amount of nitrate present in the soil at any given time. This goal can be difficult to achieve because rapidly growing crops require adequate $\mathrm{N}$. Hence, integrated agriculture is seeking for alternatives in order to achieve optimal conditions for both plants and their environment. Such an alternative may be considered the use of zeolitic tuffs as a soil conditioner to reduce nitrate leaching, and in parallel, to improve critical parameters for crops like soil humidity.

Zeolites exist in nature in many forms; a common form is the zeolitic tuff which corresponds to a rock that contains high amounts of one or more from the different $(>65)$ phases of zeolites. The zeolite with the numerous applications is the HEU-type zeolite (clinoptilolite-heulandite) that shows tabular crystals and contains micro/nanopores in a framework of channels with 10- and 8-member rings, in dimensions of $7.5 \times 3.1 \AA, 4.6 \times 3.6 \AA$ and $4.7 \times 2.8 \AA$ (Baerlocher et al., 2007; Mitchell et al., 2012). Very-high quality HEU-type zeolitic tuffs, display unique physical and chemical features and have a great variety of environmental, industrial and agricultural applications (Tsitsishvili et al., 1992; Colella and Mumpton, 2000; Filippidis and Kantiranis, 2007; Filippidis et al., 2008a, 2015a, b; Kantiranis et al., 2011; Tzamos et al., 2011; Vogiatzis et al., 2012; Filippidis, 2013). 
Using very-high quality HEU-type zeolitic tuff, the nitrate load reduction were found to be $86-92 \%$ in batch treatments of Kilkis city urban wastewaters (Filippidis et al., 2008b, 2012, 2015a; Filippidis, 2008, 2009, 2010; Filippidis and Tsirambides, 2012), 94\% in batch treatment of Thessaloniki dyeing industry wastewater (Filippidis et al., 2015b), 54-60\% in batch treatments of Sindos industrial area wastewaters (Filippidis et al., 2011a,b, 2013, 2014), 57\% in batch treatment of nitrate-solutions (Filippidis, 2007, 2010), 55\% in batch treatment of groundwater (Filippidis et al., 2006; Filippidis, 2010), and using surfactant modified clinoptilolitic zeolitic tuff, 96-97\% in batch and column treatments of groundwater (Masukume et al., 2011). In leaching experiments, $100 \%$ of the nitrate were leached from Kilkis city sewage sludge and Thessaloniki dyeing industry sludge (Filippidis $e t$ al., 2008b, 2015a, b; Filippidis, 2009; Filippidis and Tsirambides, 2012). Mixing very-high quality zeolitic tuff with sewage and dyeing industry sludge, the nitrate leaching was reduced $81-91 \%$ in the case of Zeolitic tuff + sewage sludge (Filippidis et al., 2008b, 2015a; Filippidis, 2009; Filippidis and Tsirambides, 2012) and $82 \%$ in the case of zeolitic tuff + dyeing industry sludge (Filippidis et al., 2015b). The present paper investigates the possibility of reducing the nitrate leaching by the addition-mixing the very-high quality zeolitic tuff in the agricultural soils.

\section{Materials and Methods}

\subsection{Description of experimental processing}

The field experiment was performed in the premises of Soil and Water Resources Institute (ISWR) of Hellenic Agricultural Organization "Demeter" in Sindos-Thessaloniki, Greece. The goal of the experiment was to assess nitrate leaching of irrigated agricultural soils after been treated-mixed with zeolitic tuff in different proportions; irrigation water was enriched in nitrates (totally $80 \mathrm{~L}$ with 100 $\mathrm{mg} / \mathrm{L}$ concentration) and was applied in doses following a common irrigation scheme for cultivations (see details below). The experiment took place between May and July of 2015 (10 weeks), resembling the dry conditions of a hydrological year.

The experimental procedure included the following intermediate steps:

Four (4) prototype devices were constructed; the devices included a cylinder pipe (column) of $500 \mathrm{~mm}$ diameter (internal diameter $470 \mathrm{~mm}$ ) and total length of $50 \mathrm{~cm}$, which subsequently would be filled with soil and soil-zeolitic tuff mixture in different proportions. To the lower part of the cylinder was attached a fine mesh in order to prevent sediment transport. The cylinder was based on a protected metal pan, which was intended to collect leachates from the column. The columns were roof-protected and not exposed to precipitation or any other external water source.

The next step included the sampling (bulk) of reference agricultural soils with medium soil texture from the wider area of Sindos. Samples belonged to the same soil unit, but were further homogenized with mechanic means and dried naturally (sun exposure). The lower $30 \mathrm{~cm}$ of the columns were filled with the homogenized reference soil, whilst the upper $20 \mathrm{~cm}$ were filled with the zeolitic tuff-soil mixture in three (3) different proportions, namely $0 \%$ (reference) $(\mathrm{R}), 0.2 \%(\mathrm{~A}), 0.4 \%(\mathrm{~B})$ and $0.6 \%$ (C) zeolitic tuff in the mix, respectively. The above quantities were selected intentionally as they correspond to application of 500,1000 and $1500 \mathrm{~kg}$ of zeolitic tuff per acre. These quantities are higher than the common applications used annually in agriculture, but may be achieved through the cumulative additions of zeolitic tuff quantities, hence remain on the verge of financial viability for the farmers (depending on the case).

A prototype solution of $\mathrm{KNO}_{3}$ with $100 \mathrm{mg} / \mathrm{L}$ of $\mathrm{NO}_{3}{ }^{-}$was used as irrigation water. Each irrigation dose included 2.5 litres of the prototype solution; in order to increase soil saturation and acquire efficient volume of leachates, 3 extra application doses $(41 / 2,51 / 2$ and $61 / 2$ weeks) were added between the $4^{\text {th }}$ and the $7^{\text {th }}$ week whilst the amount of irrigation water was doubled (5lt) for the applications of $5^{\text {th }}, 5 \frac{1 / 2^{\text {th }}}{}$ and $6^{\text {th }}$ week. Leachates were scheduled to be collected in a weekly timespan, but eventually a sufficient volume was acquired at the fourth week of the experiment; hence six (6) leachate samples were collected in total, from the $512^{\text {th }}$ to $10^{\text {th }}$ week. The total volume of 
irrigation water used was $40 \mathrm{~L}$ and corresponds to $260 \mathrm{~mm}$ per year. Samples were analysed immediately in the laboratories of ISWR with the use of a LAMBDA35 PERKIN-ELMER spectrophotometer.

\subsection{Analysis and characterization of soil and zeolitic tuff}

A bulk soil sample was collected from the same soil unit used in the described experimental process, for further physicochemical and mineralogical analysis. The sample was air-dried and a fraction $(<2$ $\mathrm{mm}$ ) was used for laboratory determinations. Particle size distribution was determined by the Bouyoucos hydrometer method (Gee and Bauder, 1986) and $\mathrm{pH}$ was measured in a saturation paste (Alexiadis, 1967). Cation exchange capacity (CEC) was determined by $\mathrm{CH}_{3} \mathrm{COONa}$ saturation solution of $1 \mathrm{~N}$ and $\mathrm{pH}$ of 8.5 or 7 (Bower et al., 1952). Organic matter was determined by liquid oxidation method. Finally $\mathrm{NO}_{3}-\mathrm{N}$ was determined through $\mathrm{KCl}$ extraction and $\mathrm{N}$ total with Kjeldahl method. The same methodologies were applied in zeolitic tuff physicochemical analyses.

The zeolitic tuff sample (grain-size $<0.8 \mathrm{~mm}$ ) used was supplied by ZEOVET Ouzoundis and GEOVET N. Alexandridis \& Co O.E. The mineralogical composition of the zeolitic tuff and soil sample was determined by X-Ray Powder Diffraction (XRPD). The XRPD analysis was performed using a Philips PW1710 diffractometer with Ni-filtered $\mathrm{CuK}_{\alpha}$ radiation on randomly oriented samples. The counting statistics were: start angle $3^{\circ}$, end angle $63^{\circ}(2 \theta)$, step size $0.02^{\circ}(2 \theta)$, time per step 1 sec and scan speed $0.02 \%$ sec. Semi-quantitative estimates of the abundance of the mineral phases were derived from the XRPD data, using the intensity (counts) of certain reflections, the density and the mass absorption coefficient of the identified minerals for $\mathrm{CuK}_{\alpha}$ radiation, the software MAUDMaterial Analysis Using Diffraction with the RIETVELD method. Clay mineralogy was identified from air-dried, glycolated and heat-treated oriented samples scanned from $3^{\circ}$ to $23^{\circ} 2 \theta$ at a scanning speed of $1.2 \% \mathrm{~min}$. The semi-quantitative estimation of the percentage of total amorphous materials was achieved by comparing the area of each broad background hump, which represented the amorphous materials in each sample, with the analogous area of standard mixtures of minerals with different contents of natural amorphous material, scanned under the same conditions (Filippidis and Kantiranis, 2007; Kantiranis et al., 2004, 2005, 2006).

\section{Results and Discussion}

The physicochemical determinations of soil and zeolitic tuff are presented in Table 1. Based on its texture and organic content (USDA 1987) soil sample is characterized as Sandy-Loam (SaL) with slightly alkaline $\mathrm{pH}(7.8)$; organic content is $0.6 \%$ and cation exchange capacity (CEC) is 9.5 meq/100g; total nitrogen content (Kjeldahl) is $767 \mathrm{mg} / \mathrm{kg}$ and and $\mathrm{NO}_{3}-\mathrm{N}$ is $48 \mathrm{mg} / \mathrm{kg}$. Regarding zeolitic tuff, total nitrogen is $178 \mathrm{mg} / \mathrm{kg}$ and $\mathrm{NO}_{3}-\mathrm{N} 13 \mathrm{mg} / \mathrm{kg}$, respectively.

Table 1 - Physicochemical characteristics of soil and zeolitic tuff samples.

\begin{tabular}{|c|c|c|c|c|c|c|c|c|}
\hline & \multicolumn{3}{|c|}{ Texture } & CEC & pH & Organic C & $\begin{array}{c}\text { Ntotal } \\
\text { (Kjeldahl) }\end{array}$ & NO3-N \\
\cline { 2 - 9 } & Sand (\%) & Silt (\%) & Clay (\%) & meq/100g & & $\%$ & $\mathrm{mg} / \mathrm{kg}$ & $\mathrm{mg} / \mathrm{kg}$ \\
\hline Soil & 62 & 22 & 16 & 9.5 & 7.8 & 0.6 & 767 & 48 \\
\hline zeolitic tuff & - & - & - & - & - & - & 178 & 13 \\
\hline
\end{tabular}

The semi-quantitative mineralogical compositions of the zeolitic tuff and soil sample are presented in Table 2 and Figures 1 and 2. Zeolitic tuff contains 88 wt.\% HEU-type zeolite (clinoptiloliteheulandite), $5 \mathrm{wt} . \%$ mica + clay minerals, $4 \mathrm{wt} . \%$ quartz, $2 \%$ amorphous materials and $1 \%$ feldspars. Soil sample contains 59 wt.\% quartz, 21 wt.\% feldspars, 15 wt.\% micas+clay minerals and 5 wt. $\%$ amphibole.

Based on the analytical results of leachates, nitrate load is decreased significantly in zeolite treated soils compared with the reference (untreated) sample. The initial concentration (5.5 week) of nitrates 
in R sample is $894 \mathrm{mg} / \mathrm{L}$, whilst the initial concentrations in leachates of $\mathrm{A}, \mathrm{B}$ and $\mathrm{C}$ samples are 554,471 and $458 \mathrm{mg} / \mathrm{L}$ respectively, corresponding to a decreased concentration of $38,47 \%$ and $49 \%$ of initial R leachates (Table 3 and Figure 3).

Table 2 - Semi-quantitative mineralogical composition of Zeolitic tuff and soil samples.

\begin{tabular}{|lc|lc|}
\hline \multicolumn{1}{|c|}{ Zeolitic tuff } & \multicolumn{2}{c|}{ Soil } & Wt.\% \\
Minerals & Wt.\% & Minerals & 59 \\
\hline HEU-type zeolite (clinoptilolite-heulandite) & 88 & Quartz & 21 \\
\hline Micas + Clay-minerals & 5 & Feldspars & 15 \\
\hline Quartz & 4 & Micas + Clay-minerals & 5 \\
\hline Feldspars & 1 & Amphibole & 100 \\
\hline Amorphous & 2 & & \\
\hline Total & 100 & Total & \\
\hline
\end{tabular}

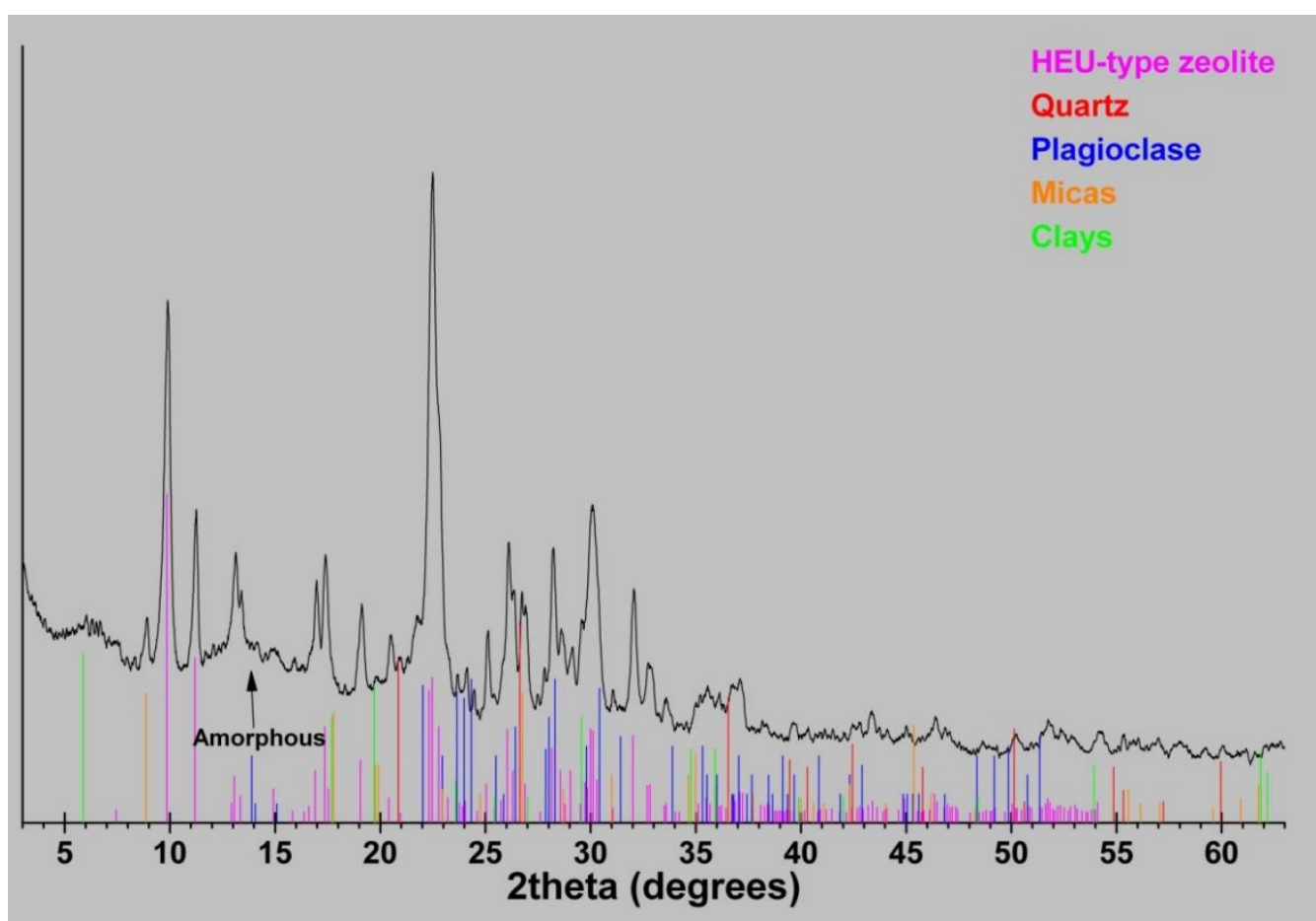

Figure 1 - X-Ray Powder Diffraction pattern of zeolitic tuff sample.

Taken into account that experimental conditions are similar and that soil organic content is in general low $(0.6 \%)$, it is evident that this significant decrease should be attributed to zeolitic tuff impact. Subsequently, intermediate of the experimental process ( $8^{\text {th }}$ week), nitrate load concentrations decrease with different rates for A, B and C samples, corresponding to a reduction of $26 \%, 50 \%$ and $55 \%$ compared to $\mathrm{R}$ leachates. In general, $\mathrm{R}$ and $\mathrm{A}$ samples follow similar decrease rates for nitrates, denoting an insignificant impact of the $0.2 \%$ zeolitic tuff content in soil. This may also be deduced by the concentrations of nitrate load at the end of experiment $\left(10^{\text {th }}\right.$ week), which differ only by 2 $\mathrm{mg} / \mathrm{L}(2 \%)$, corresponding to a negligible variation within the standard analytical error. On the contrary, it is rather promising that the final concentrations of nitrate load in samples B and C, has been decreased significantly compared to R sample by $81 \%$ and $86 \%$, respectively. 


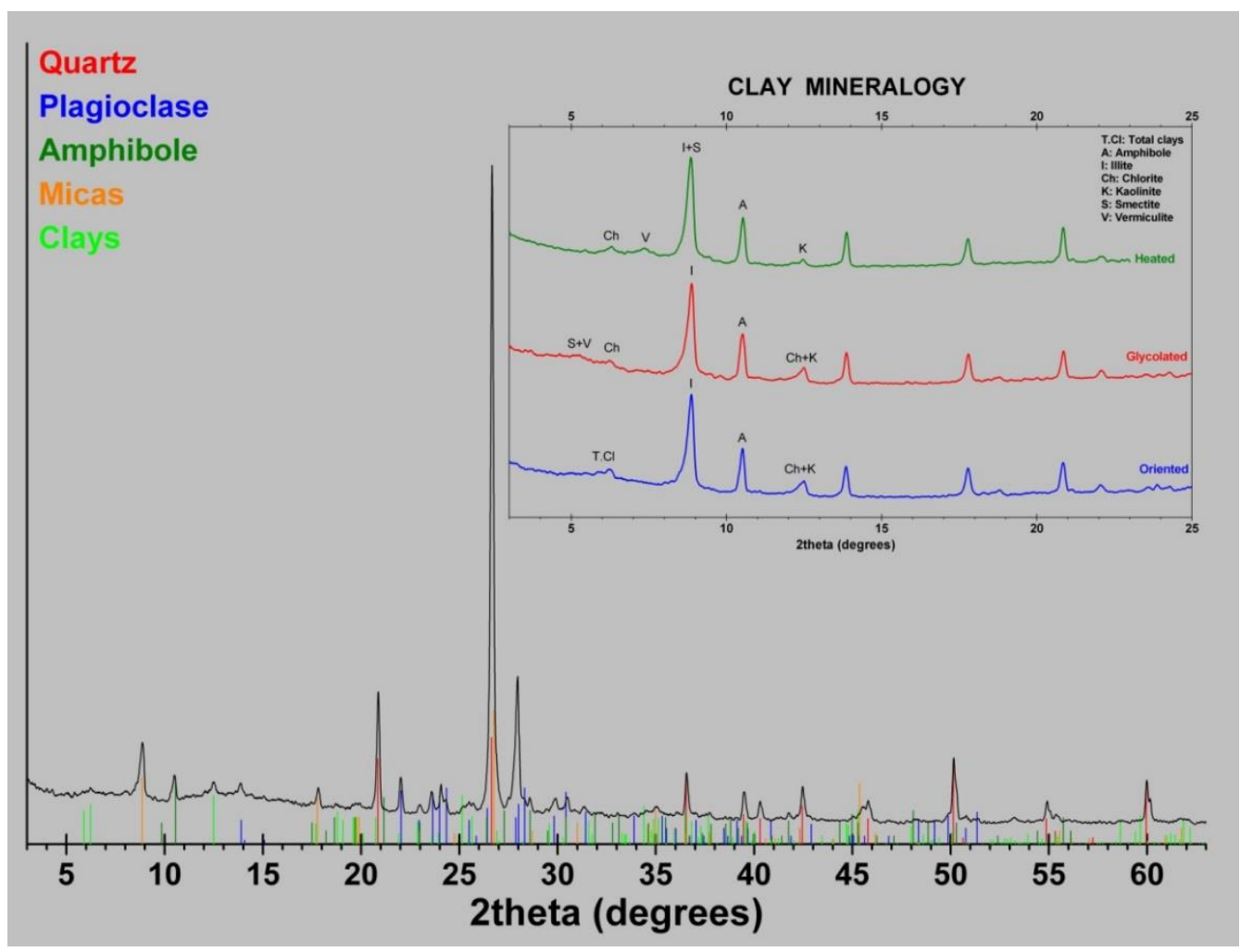

Figure 2 - X-Ray Powder Diffraction pattern of soil sample. Clay mineralogy: Illite, smectite, kaolinite, vermiculite and chlorite.

Table 3 - Percentages of nitrate load reduction in leachates compared to reference sample.

\begin{tabular}{|c|c|c|c|}
\hline & Start $\mathbf{( 5 . 5}^{\text {th }}$ week) & Intermediate $\mathbf{( 8}^{\text {th }}$ week) & End (10 $^{\text {th }}$ week) \\
\hline Reference (R) & $894 \mathrm{mg} / \mathrm{L}$ & $162 \mathrm{mg} / \mathrm{L}$ & $81 \mathrm{mg} / \mathrm{L}$ \\
\hline $\mathbf{0 . 2} \% \mathbf{Z}(\mathbf{A})$ & $38 \%$ & $26 \%$ & $2 \%$ \\
\hline $\mathbf{0 . 4} \% \mathbf{Z}(\mathbf{B})$ & $47 \%$ & $50 \%$ & $81 \%$ \\
\hline $\mathbf{0 . 6} \% \mathbf{Z}(\mathbf{C})$ & $49 \%$ & $55 \%$ & $86 \%$ \\
\hline
\end{tabular}

The results of nitrate load reduction obtained from soil mixing with natural HEU-type zeolitic tuff (ZT) are rather successful; nitrate load was decreased in $0.4 \%$ ZT sample by $81 \%$, whilst in $0.6 \%$ ZT sample by $86 \%$. So far, similar decrease percentages have been recorded using very-high quality HEU-type zeolitic tuff and surfactant modified clinoptilolitic zeolitic tuff, (86-92\%) in batch treatments of urban wastewaters (Filippidis et al., 2008b, 2012, 2015a; Filippidis, 2008, 2009, 2010; Filippidis and Tsirambides, 2012), (94\%) in batch treatment of dyeing industry wastewater (Filippidis et al., 2015b), (54-60\%) in batch treatments of industrial area wastewaters (Filippidis et al., 2011a,b, 2013, 2014), (57\%) in batch treatment of nitrate-solutions (Filippidis, 2007, 2010), $(55 \%)$ in batch treatment of groundwater (Filippidis et al., 2006; Filippidis, 2010), and (96-97\%) in batch and column treatments of groundwater (Masukume et al., 2011). In leaching experiments, $100 \%$ of the nitrate were leached from Kilkis city sewage sludge and Thessaloniki dyeing industry sludge (Filippidis et al., 2008b, 2015a, b; Filippidis, 2009; Filippidis and Tsirambides, 2012). Mixing very-high quality zeolitic tuff with sewage and dyeing industry sludge, the nitrate leaching was reduced $81-91 \%$ in the case of Zeolitic tuff + sewage sludge (Filippidis et al., 2008b, 2015a; Filippidis, 2009; Filippidis and Tsirambides, 2012) and 82\% in the case of zeolitic tuff + dyeing 
industry sludge (Filippidis et al., 2015b); nevertheless zeolite modification is a non viable process in financial terms for common agricultural practices. In comparison with this study, nitrate removal with a zeolitic rock (70-75 wt.\% clinoptilolite) achieved percentages of less of than $10 \%$ (Mazeikiene et al., 2008), and proved to be an insufficient for nitrate retention.

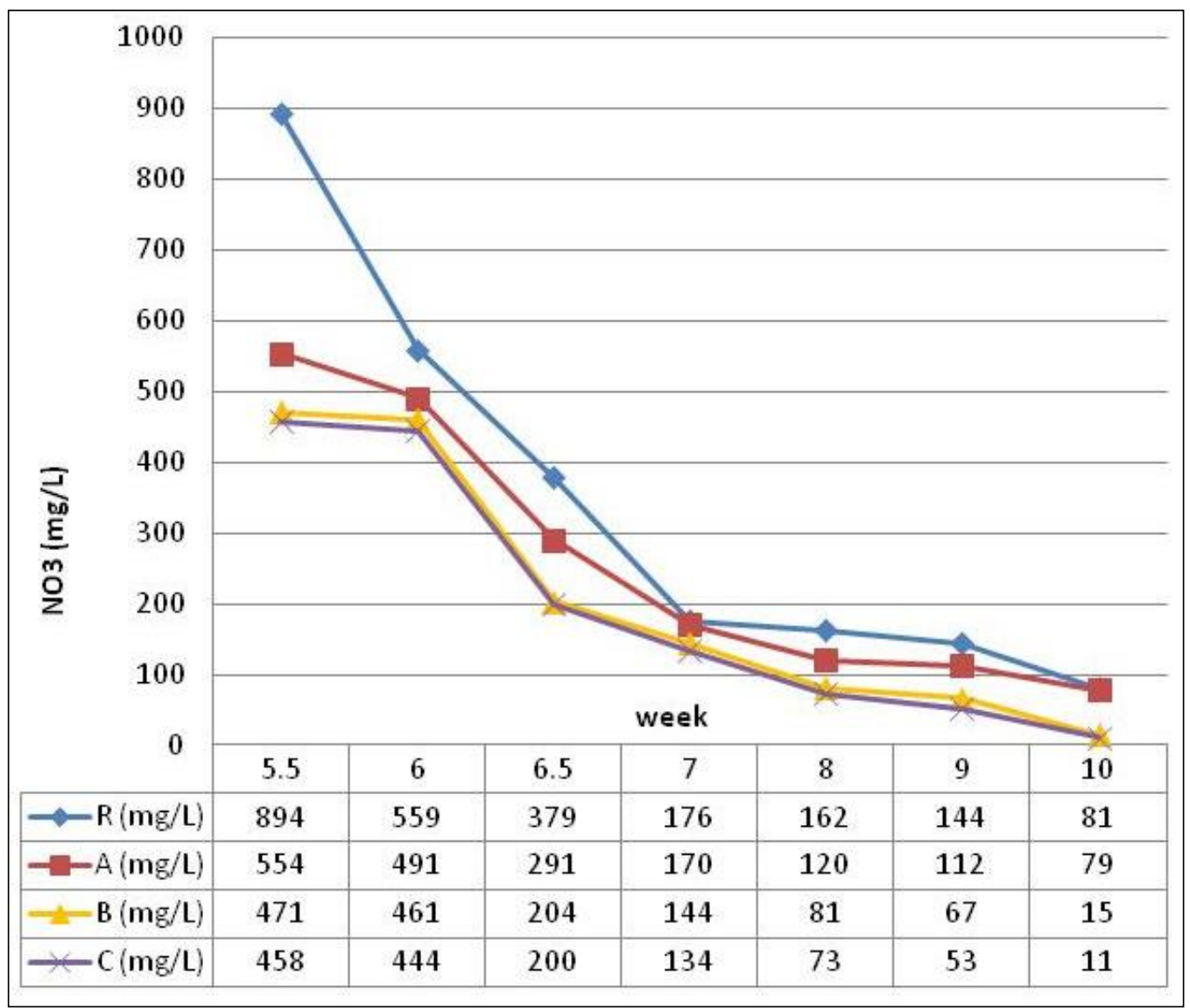

Figure 3 - Nitrate load concentrations in leachates.

On the contrary, the used very-high quality HEU-type zeolitic tuff has proven to be a unique sorbent of bacteria, gases, inorganic, organic and organometallic compounds, and achieves to buffer $\mathrm{pH}$ of soils and waters to neutral (e.g., Filippidis and Kantiranis, 2007; Filippidis et al., 2008a, b, 2015a, b; Filippidis, 2010, 2013). The sorption and fixation of the different components from their solutions by the micro/nano-pores of HEU-type zeolite, as well as from meso- and macro-pores of the zeolitic tuff, is attributed to absorption (ion exchange), adsorption and surface precipitation processes (Godelitsas et al., 1999, 2001, 2003; Fu and Wang, 2011; Kantiranis et al., 2011; Malamis and Katsou, 2013). The HEU-type zeolite is characterized by Brønsted acidic and the Lewis basic active sites, that react with the negatively or/and positively charged chemical components, even with molecules in gas condition. These chemical processes are related to sorption and fixation physicochemical phenomena of ions and molecules, and are related both to the structural void spaces (micro/nano-pores) and the surface of the HEU-type zeolite crystals, consequently the meso- and macro-pores of the zeolitic tuff. Finally, HEU-type zeolite shows an ability to neutralize the $\mathrm{pH}$ of acidic and basic waters, acting either as a proton acceptor or donor, exhibiting thus an amphoteric character (Misaelides et al., 1995; Godelitsas et al., 1999, 2001, 2003; Kantiranis et al., 2011). 


\section{Conclusions}

A very-high quality HEU-type zeolitic tuff containing $88 \mathrm{wt}$ \% clinoptilolite-heulandite, has been used as a mixing material with soil samples from Sindos area, Thessaloniki. Zeolitic tuff-soil mixture was added on the top $20 \mathrm{~cm}$ of a totally $50 \mathrm{~cm}$ column (the remaining covered with untreated soil) in different proportions $(0.2,0.4$ and $0.6 \%$ ) corresponding to an application of 500, 1000 and $1500 \mathrm{~kg}$ per acre. Samples were subjected to common irrigation scheme with stable doses, simulating a total volume of $40 \mathrm{~L}$ or $260 \mathrm{~mm}$ per year. Results revealed that zeolitic tuff mixture may act as an efficient natural sorbent with a remarkable ability to retain nitrate leachates from soils, up $86 \%$ of the initial leachates of the reference (untreated) sample. The maximum retention percentage was achieved with a $0.6 \%$ addition of zeolitic tuff, which is still under conditions within the margins of financial viability form common farmers. However, results should be further exploited and verified in field conditions, with real irrigation and cultivations schemes, and external effects. Nevertheless, the results obtained in laboratory scale from this study are quite promising for the efficacy of zeolitic tuff as natural sorbent and its contribution to rational agricultural practices against nitrate contamination. The latter is in line with the objectives of the new common EU agricultural policy, and may act as a supplementary tool for integrated fertilization, water resources management and environmental protection.

\section{Acknowledgments}

The authors wish to thank GEO-VET N. Alexandridis \& Co O.E. for the supply of the zeolitic tuff.

\section{References}

Alexiadis, K., 1967. Physical and chemical soil analysis. Thessaloniki, 78 pp. (in Greek).

Baerlocher, Ch., McCuster, L.B. and Olson, D.H., 2007. Atlas of Zeolite Framework Types. Amsterdam, Elsevier, 301 pp.

Bower, C.A., Reitemeier, R.F. and Fireman, M., 1952. Exchangeable cation analysis of saline and alkali soils, Soil Sci. 73, 251-261

Colella, C. and Mumpton, F.A., 2000. Natural Zeolites for the Third Millenium, Napoli, De Frede Editore, $481 \mathrm{pp}$.

Council Directive 1991/676/EEC of 12 December 1991 concerning the protection of waters against pollution caused by nitrates from agricultural sources.

Filippidis, A., 2007. Zeolites of Trigono Municipality of Evros Prefecture in industrial, agricultural, cattle-raising and environmental technology (in Greek), Proc. Sci. Meet. Development Perspectives of Northern Evros, Petrota, Evros, Greece, 4 Aug., 89-107.

Filippidis, A., 2008. Treatment and recycling of municipal and industrial waste waters using Hellenic Natural Zeolite: A Review, Proc. AQUA, $3^{\text {rd }}$ Intern. Conf. Water Sci. \& Technology, Athens, 16-19 Oct., 5 pp.

Filippidis, A., 2009. Management of urban and industrial wastewaters using Hellenic Natural Zeolite. Review article (in Greek with English summary), Proc. Congr. Integrated Manag. Water Res. Climatic Change Conditions, Volos, Greece, 27-30 May, II, 829-836.

Filippidis, A., 2010. Environmental, industrial and agricultural applications of Hellenic Natural Zeolite, Hellenic J. Geosci., 45, 91-100.

Filippidis, A., 2013. Industrial and municipal wastewater treatment by zeolitic tuff, Water Today $\mathrm{V}(\mathrm{X}), 34-38$.

Filippidis, A. and Kantiranis, N., 2007. Experimental neutralization of lake and stream waters from N. Greece using domestic HEU-type rich natural zeolitic material, Desalination, 213, 47-55.

Filippidis, A. and Tsirambides, A., 2012. Quality characteristics of the Greek zeolites, environmental, industrial, agricultural and aquacultural uses of Hellenic natural zeolite: A review (in Greek with English abstract), Scientific Annals, School of Geology, Aristotle University of Thessaloniki, 101, 125-133. 
Filippidis, A., Kantiranis, N., Drakoulis, A. and Vogiatzis, D., 2006. Improvement and protection of the lake Koronia using natural zeolite (In Greek with English summary), Proc. $2^{\text {nd }}$ Congr. Aristotle Univ. Environ. Council, Thessaloniki, 1-4 June, 273-279.

Filippidis, A., Apostolidis, N., Paragios, I. and Filippidis, S., 2008a. Zeolites clean up, Industrial Minerals, 487, 68-71.

Filippidis, A., Apostolidis, N., Paragios, I. and Filippidis, S., 2008b. Safe management of sewage sludge, produced by treatment of municipal sewage with Hellenic Natural Zeolite, Proc.

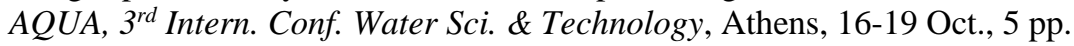

Filippidis, A., Tsirambides, A., Kantiranis, N., Tzamos, E., Vogiatzis, D., Papastergios, G., Papadopoulos, A. and Filippidis S., 2011a. Purification of wastewater from Sindos industrial area of Thessaloniki (N. Greece) using Hellenic Natural Zeolite, Proc. ${ }^{\text {th }}$ Intern. Hydrogeol. Congr., Kalavrita, Greece, 5-8 Oct., Environ. Earth Sci., Springer, Berlin, Adv. Res. Aquatic Environ., 2, 435-442.

Filippidis, A., Tsirambides, A., Tzamos, E., Vogiatzis, D., Papastergios, G., Georgiadis, I., Papadopoulos, A. and Filippidis, S., 2011b. Purification of wastewater from Thessaloniki industrial area using Hellenic natural zeolite (in Greek with English abstract), Proc. $21^{\text {st }}$ Panhellenic Chemistry Congr., Thessaloniki, 9-12 Dec., 8 pp.

Filippidis, A., Kantiranis, N., Vogiatzis, D., Tzamos, E., Papastergios, G. and Filippidis, S., 2012. Odourless-cohesive zeosewage sludge production and urban wastewater purification by natural zeolite, Proc. Intern. Conf. Protection \& Restoration Environment XI, Thessaloniki, 3-6 July, 582-588.

Filippidis, A., Godelitsas, A., Kantiranis, N., Gamaletsos, P., Tzamos, E. and Filippidis, S., 2013. Neutralization of sludge and purification of wastewater from Sindos industrial area of Thessaloniki (Greece) using natural zeolite, Bull. Geol. Soc. Greece, 47(2), 920-926.

Filippidis, A., Kantiranis, N., Tziritis, E., Tzamos, E., Vogiatzis, D. and Filippidis, S., 2014. The use of Hellenic Natural Zeolite (HENAZE) in the purification of Thessaloniki industrial area wastewaters, Proc. $10^{\text {th }}$ Intern. Hydrogeol. Congr., Thessaloniki, 8-10 Oct., 187-193.

Filippidis, A., Kantiranis, N., Papastergios, G. and Filippidis, S., 2015a. Safe management of municipal wastewater and sludge by fixation of pollutants in very high quality HEU-type zeolitic tuff, J. Basic Appl. Res. Intern., 7(1), 1-8.

Filippidis, A., Papastergios, G., Kantiranis, N. and Filippidis, S., 2015b. Neutralization of dyeing industry wastewater and sludge by fixation of pollutants in very high quality HEU-type zeolitic tuff, J. Global Ecol. Environ., 2(4), 221-226.

Fu, F. and Wang, Q., 2011. Removal of heavy metal ions from wastewaters: A review, J. Envir. Manag., 92, 407-418.

Gee, G. and Bauder, J., 1986. Particle Size Analysis. In: Klute, A., eds., Methods of Soil Analyses, Part 2, 2nd American Society of Agronomy and Soil Science Society of America: Madison, WI, 9, 383-411.

Godelitsas, A., Charistos, D., Dwyer, J., Tsipis, C., Filippidis, A., Hatzidimitriou, A. and Pavlidou, E., 1999. Copper (II)-loaded HEU-type zeolite crystals: characterization and evidence of surface complexation with N,N-diethyldithiocarbamate anions. Microporous \& Mesoporous Materials, 33, 77-87.

Godelitsas, A., Charistos, D., Tsipis, A., Tsipis, C., Filippidis, A., Triantafyllidis, C., Manos, G. and Siapkas, D., 2001. Characterisation of zeolitic materials with a HEU-type structure modified by transition metal elements: Definition of acid sites in Nickel-loaded crystals in the light of experimental and quantum-chemical results, Chemistry-A European Journal, 7, 3705-3721.

Godelitsas, A., Charistos, D., Tsipis, C., Misaelides, P., Filippidis, A. and Schindler, M., 2003. Heterostructures patterned on aluminosilicate microporous substrates: Crystallisation of cobalt (III) tris (N,N-diethyl-dithiocarbamato) on the surface of HEU-type zeolite. Microporous \& Mesoporous Materials, 61, 69-77.

Kantiranis, N., Filippidis, A. and Georgakopoulos, A., 2005. Investigation of the uptake ability of fly ashes produced after lignite combustion, J. of Environmental Management, 76, 119-123. 
Kantiranis, N., Filippidis, A., Mouhtaris, T., Paraskevopoulos, K.M., Zorba, T., Squires, C. and Charistos, D., 2006. EPI-type zeolite synthesis from Greek sulphocalcic fly ashes promoted by $\mathrm{H}_{2} \mathrm{O}_{2}$ solutions, Fuel, 85, 360-366.

Kantiranis, N., Georgakopoulos, A., Filippidis, A. and Drakoulis, A., 2004. Mineralogy and organic matter content of bottom ash samples from Agios Dimitrios power plant, Greece, Bull. Geol. Soc. Greece, 36(1), 320-326.

Kantiranis, N., Sikalidis, K., Godelitsas, A., Squires, C., Papastergios, G. and Filippidis, A., 2011. Extra-framework cation release from heulandite-type rich tuffs on exchange with $\mathrm{NH} 4+, J$. Environ. Management, 92, 1569-1576.

Lichtenberg, E. and Shapiro, L.S., 1997. Agriculture and nitrate concentrations in Maryland community water system wells, J. Environ. Qual., 26, 145-153.

Malamis, S. and Katsou, E., 2013. A review on zinc and nickel adsorption on natural and modified zeolite, bentonite and vermiculite: Examination of process parameters, kinetics and isotherms, J. of Hazar. Mater., 252/253, 428-461.

Masukume, M., Onyango, M.S., Aoyi O. and Otieno, F., 2011. Nitrate removal from groundwater using modified matural zeolite, Tshwane University of Technology, Department of Chemical and Matallurgical Engineering, South Africa, Res. Rep., 13 pp.

Mazeikiene, A., Valentukeviciene, M., Rimeika, M., Matuzevicius, A.B. and Dauknys, R., 2008. Removal of nitrates and ammonium ions from water using natural sorbent zeolite (clinoptilolite), J. Envir. Eng. Landsc. Manag., 16, 38-44.

Misaelides, P., Godelitsas, A., Filippidis, A., Charistos, D. and Anousis, I., 1995. Thorium and uranium uptake by natural zeolitic materials, Sci. Total Environment, 173/174, 237-246.

Mitchell, S., Michels, N.L., Kunze, K. and Perez-Ramirez, J., 2012. Visualization of hierarchically structured zeolite bodies from macro to nano length scales, Nature Chemistry, 4, 825-831.

Perrin, S., Drost, D., Boettinger, J. and Norton, J., 1998. Ammonium-Loaded Clinoptilolite: A SlowRelease Nitrogen Fertilizer for Sweet Corn, J. of PNutrition, 21(3), 515-530.

Tsitsishvili, G.V., Andronikashvili, T.G., Kirov, G.N. and Filizova, L.D., 1992. Natural Zeolites, Chichester, England, Ellis Horwood Ltd, 295 pp.

Tzamos, E., Kantiranis, N., Papastergios, G., Vogiatzis, D., Filippidis, A. and Sikalidis, C., 2011. Ammonium exchange capacity of the Xerovouni zeolitic tuffs, Avdella area, Evros Prefecture, Greece, Clay Minerals, 46,179-187.

Vogiatzis, D., Kantiranis, N., Filippidis, A., Tzamos, E. and Sikalidis, C., 2012. Hellenic Natural Zeolite as a replacement of sand in mortar: mineralogy monitoring and evaluation of its influence on mechanical properties, Geosciences, 2, 298-307.

USDA, 1987. United States Department of Agriculture (USDA), Textural Soil Classification (Module 3), Soil Mechanics Level -1, Technical report, 48 pp. 